Kazuo Kamitani MD, Akiko Higuchi $M D$, Takeshi Takebayashi MD, Yuko Miyamoto MD, Hitoshi Yoshida MD

\section{Covering the head and face maintains intraop- erative core temperature}

Purpose: To determine the effect of covering the patient's head and face on the prevention of intraoperative hypothermia $\left(<35.5^{\circ} \mathrm{C}\right)$.

Methods: This randomized, prospective trial included 44 adults undergoing elective abdominal surgery. After the induction of anesthesia with thiopental, in 44 patients their extremities and trunk were covered with towels and sheets. In addition, 22 patients (covered group) had their face and head fully covered. Anesthesia was maintained with $\mathrm{N}_{2} \mathrm{O} 50-66 \%\left(2-3 \mathrm{~L} \cdot \mathrm{min}^{-1}\right)$ and isoflurane (<IMAC) in oxygen combined with thoracic epidural anesthesia. Core temperature was measured at the tympanic membrane continuously and was recorded at 15 min intervals from the induction of anesthesia. Heat and moisture exchangers were used in their anesthetic circuit. Ambient temperature was maintained near $25^{\circ} \mathrm{C}$.

Results: Neither group demonstrated intraoperative hypothermia. However, tympanic membrane temperature at $75,90,105 \mathrm{~min}$ in the covered group were higher than those of control group $\left(36.7 \pm 0.4^{\circ} \mathrm{C}\right.$ vs $36.5 \pm 0.4^{\circ} \mathrm{C}$ $36.8 \pm 0.5^{\circ} \mathrm{C}$ vs $36.4 \pm 0.5^{\circ} \mathrm{C}, 36.8 \pm 0.5^{\circ} \mathrm{C}$ vs $36.4 \pm 0.5^{\circ} \mathrm{C}$, respectively, $\left.P<0.05\right)$.

Conclusion: Covering the patient's head and face maintains intraoperative core temperature.

Objectif : Déterminer si le fait de couvrir la tête et le visage des patients contribue à prévenir l'hypothermie peropératoire $\left(<35,5^{\circ} \mathrm{C}\right)$.

Méthode : L'essai randomisé et prospectif a porté sur 44 adultes subissant une intervention abdominale élective. Après l'induction de l'anesthésie avec du thiopental, on a couvert les extrémités et le tronc des 44 patients de serviettes et de draps. De plus, pour 22 d'entre eux (le groupe couvert), on a aussi couvert complètement le visage et la tête. On a maintenu l'anesthésie avec du $\mathrm{N}_{2} \mathrm{O} 50-66 \%\left(2-3 \mathrm{~L} \cdot \mathrm{min}^{-1}\right)$ et de l'isoflurane (<ICAM) mêlé à de l'oxygène, combiné à une anesthésie péridurale thoracique. On a procédé à une mesure continue de la température centrale, à la membrane tympanique, et on l'a notée aux 15 min depuis l'induction de l'anesthésie. Les échangeurs de chaleur et d'humidité ont été intégrés au circuit anesthésique. La température ambiante a été maintenue autour de $25^{\circ} \mathrm{C}$.

Résultats : Aucun des patients n'a présenté d'hypothermie peropératoire. Cependant, la température prélevée à la membrane tympanique à 75,90 et 105 min dans le groupe couvert était plus élevée que dans le groupe témoin $\left(36,7 \pm 0,4^{\circ} \mathrm{C}\right.$ vs $36,5 \pm 0,4^{\circ} \mathrm{C}, 36,8 \pm 0,5^{\circ} \mathrm{C}$ vs $36,4 \pm 0,5^{\circ} \mathrm{C}, 36,8 \pm 0,5^{\circ} \mathrm{C}$ vs $36,4 \pm 0,5^{\circ} \mathrm{C}$ respectivement, $P<0,05)$.

Conclusion : Couvrir la tête et le visage maintient la température centrale peropératoire.

From Department of Anesthesia, Toyama Prefectural Central Hospital, 2-2-78 Nishinagae, Toyama city, Toyama 930-8550, Japan. Address correspondence to: Dr. K. Kamitani, Phone: 0764-24-1531; Fax: 0764-22-0667.

Accepted for publication April 4, 1999 
$\mathrm{H}$ YPOTHERMIA during anesthesia potentially causes complications including myocardial infarction, ${ }^{1}$ surgical wound infection, ${ }^{2,3}$ shivering, ${ }^{4}$ increased intraoperative blood loss, ${ }^{5}$ delayed recovery from neuromuscular blockade, ${ }^{6}$ and early postoperative morbid cardiac events. ${ }^{7}$ Induction of general anesthesia increases cutaneous heat loss. ${ }^{8}$ So, covering the patient's skin surface with a cloth is expected to prevent intraoperative hypothermia, although it is unlikely that skin surface insulation alone can prevent immediate postinduction hypothermia. ${ }^{9}$

In this study, the head and face were covered with towels and sheets. It is likely that the amount of skin surface covered is important in the prevention of cutaneous heat loss. ${ }^{9}$ Thus, we investigated the efficacy of this method on core temperature during abdominal surgery.

\section{Methods}

This randomized, prospective trial included 44 adult patients, ASA I-III, undergoing elective abdominal surgery. Patients who had preoperative fever or who receive a vasodilator on day surgery were excluded.

All patients were premedicated with atropine and hydroxyzine. An epidural catheter was placed using standard technique between $\mathrm{T}_{6-10}$ interspace. Anesthesia was induced with $5 \mathrm{mg} \cdot \mathrm{kg}^{-1}$ thiopental and muscle relaxation was achieved with $0.15 \mathrm{mg} \cdot \mathrm{kg}^{-1}$ vecuronium. After tracheal intubation, anesthesia was maintained with $\mathrm{N}_{2} \mathrm{O} 50-66 \%\left(2-3 \mathrm{~L} \cdot \mathrm{min}^{-1}\right)$ and isoflurane ( $<1 M A C)$ in oxygen combined with supplemental administration of lidocaine $1.5 \%$ epidurally. If systolic blood pressure decreased below $90 \mathrm{mmHg}, 4-10 \mathrm{mg}$ ephedrine iv were administered. Mechanical ventilation was adjusted to maintain $\mathrm{P}_{\mathrm{ET}} \mathrm{CO}_{2}$ near 35 $\mathrm{mmHg}$. Heat and moisture exchangers were used in the anesthetic circuit. Ambient temperature was maintained near $25^{\circ} \mathrm{C}$.

After induction of anesthesia, the extremities and trunk of all patients were covered with towels and aluminized reflective sheets. In addition, in a randomized group of 22 patients (covered group) the head and face were covered fully (Figure 1). Core temperature was measured at the tympanic membrane using a Mon-a-Therm thermocouple (Mallinckrodt, St. Louis, MO) continuously and was recorded at $\mathbf{1 5} \mathrm{min}$ intervals from the induction of anesthesia.

For statistical analysis, changes in core temperature over time during each treatment and differences between treatments at each time were evaluated using repeated measures ANOVA and Scheffe's F tests. The comparison of group demographic variables werc ana-
TABLE Characteristics of patients and anesthesia

\begin{tabular}{lll}
\hline & control group & covered group \\
\hline Age $(\mathrm{yr})$ & $66.3 \pm 9.4$ & $67.5 \pm 9.6$ \\
Heighr $(\mathrm{cm})$ & $158.0 \pm 8.2$ & $158.7 \pm 10.4$ \\
Weight $(\mathrm{kg})$ & $54.7 \pm 9.9$ & $57.3 \pm 7.8$ \\
ASA Status & $2.1 \pm 0.5$ & $2.1 \pm 0.4$ \\
$\begin{array}{l}\text { Duration of surgery }(\mathrm{min}) \\
\text { The amount doses of }\end{array}$ & $130.5 \pm 32.9$ & $136 . \pm 33.8$ \\
ephedrine (mg) & & \\
Fluid volume (ml) & $5.55 \pm 3.31$ & $5.86 \pm 3.44$ \\
Hemorrhage volume $(\mathrm{ml})$ & $2599.7 \pm 782.3$ & $2874.1 \pm 839.7$ \\
\hline
\end{tabular}

lyzed using unpaired $t$ test. Data are expressed as mean $\pm S D ; P<0.05$ identified statistically significant differences.

\section{Results}

The two groups did not differ with regard to age, weight, height, ASA status, the amount and doses of ephedrine, duration of surgery, volume of intravenous fluid, or volume of hemorrhage (Table). Data of tympanic temperature are shown in Figure 2. Both groups did not experience intraoperative hypothermia $\left(<35 \cdot 5^{\circ} \mathrm{C}\right)$. However, the tympanic membrane temperatures at 75,90,105 min in the covered group were higher than those in the control group. In the control group, the tympanic membranous temperature at $\mathbf{1 0 5} \mathrm{min}$ was lower than at $0 \mathrm{~min}$ (Figure 2).

\section{Discussion}

Because maintenance of body temperature is an important aspect of anesthetic management, various methods have been used to prevent intraoperative hypothermia $\left.\left(<35.5^{\circ} \mathrm{C}\right)\right)^{9-15}$ Most are performed under the ambient temperature $20-22^{\circ} \mathrm{C}$. The body temperature can be influenced by the ambient tem-

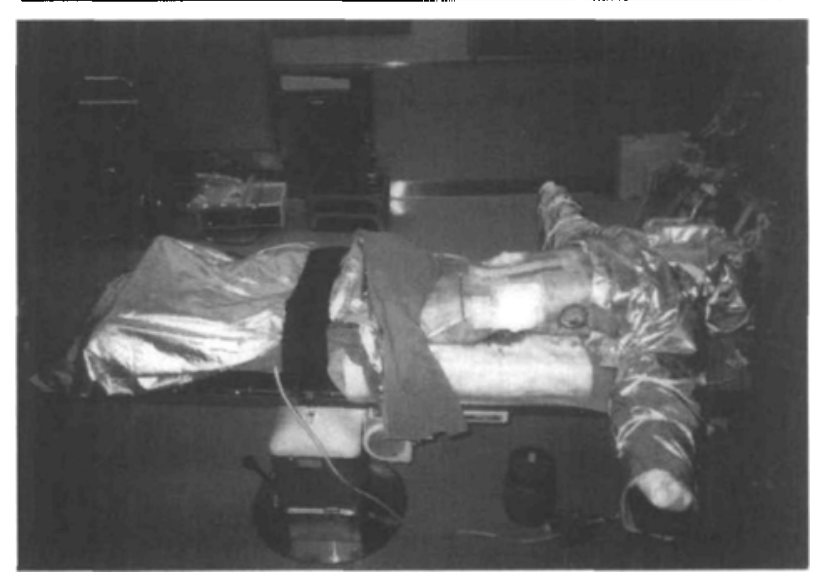

FIGURE 1 Photograph of covered group 


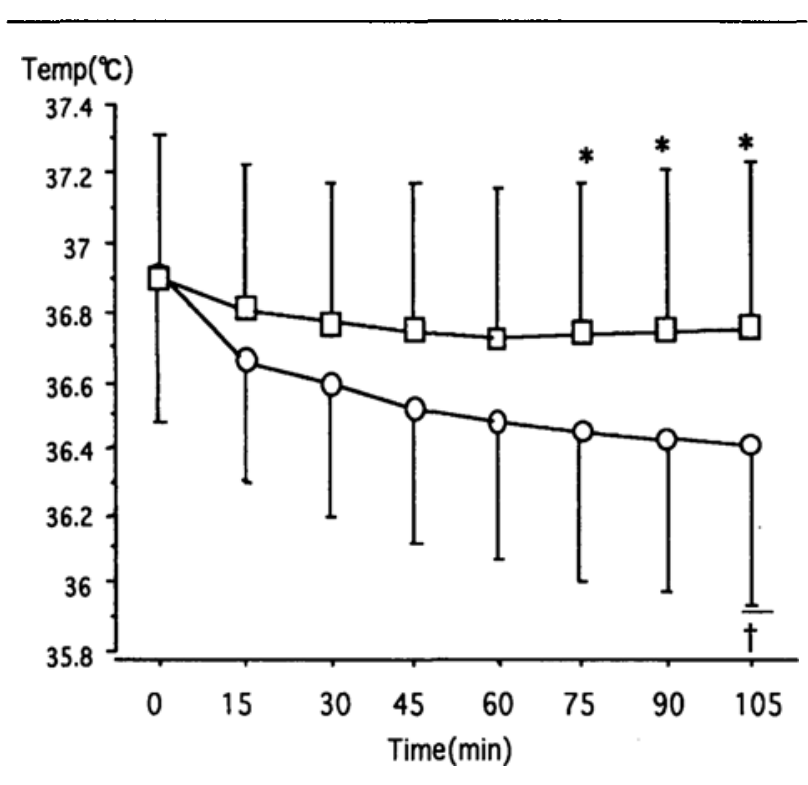

FIGURE 2 Tympanic temperature measurements.

$\square$ : covered group $O$ : control group.

Data was presented as mean $\pm S D$.

${ }^{*} ; P<0.05$ vs control group $t ; P<0.05$ vs value at 0 min.

perature under general anesthesia. At our institution, intraoperative hypothermia is rare because the ambient temperature is usually maintained near $25^{\circ} \mathrm{C}$. However, we recognized intraoperative hypothermia even with this ambient temperature, especially in cases of long abdominal surgery. Thus, we covered the head and face with towels and sheets in addition to the usual covering. This method is very convenient in preventing cutaneous heat loss; it is technically easy and cheap. Our results showed that the core temperature remained normothermic in both groups, but that the core temperatures at $75,90,105 \mathrm{~min}$ in the covered group were higher than those in the control group.

One potential limitation of our results was the use of tympanic temperature as a measure of core temperature. Shiraki et al. ${ }^{16}$ reported that tympanic temperature was influenced by active cooling of the face. However, we did not cool or heat the face. Thus, our results represent changes of core temperature rather than of surface temperature. The effect of covering the head and face at ambient temperatures $20-22^{\circ} \mathrm{C}$ is not known. However, we should make efforts to prevent intraoperative hypothermia whenever possible.

We conclude that covering the head and face helps prevent intraoperative hypothermia. Further investigations are needed to clarify factors which influence tympanic temperature.

\section{References}

I Frank SM, Beattie C, Christopherson R, et al.

Unintentional hypothermia is associated with postoperative myocardial ischemia. Anesthesiology 1993; 78: 468-76.

2 Sheffield CW, Sessler DI, Hunt TK. Mild hypothermia during isoflurane anesthesia decreases resistance to $E$. coli dermal infection in guinea pigs. Acta Anaesthesiol Scand 1994; 38: 201-5.

3 Kurz A, Sessler DI, Lenbardt R. Perioperative normothermia to reduce the incidence of surgical-wound infection and shorten hospitalization. New Engl J Med 1996; 334: 1209-15.

4 Sessler DI, Israel D, Pozos RS, Pozos M, Rubinstein EH. Spontaneous post-anesthetic tremor does not resemble thermoregulatory shivering. Anesthesiology 1988; 68: 843-50.

5 Schrnied H, Kurz A, Sessler DI, Kozek S, Reiter A. Mild hypothermia increases blood loss and transfusion requirements during total hip arthroplasty. Lancet 1996; 347: 289-92.

6 Heier T, Caldwell JE, Sessler DI, Miller RD. Mild intraoperative hypothermia increases duration of action and spontaneous recovery of vecuronium blockade during nitrous oxide-isoflurane anesthesia in humans.

Anesthesiology 1991; 74: 815-9.

7 Frank SM, Fleisher LA, Breslow MJ, et al. Perioperative maintenance of normothermia reduces the incidence of morbid cardiac events. A randomized clinical trial.

JAMA 1997; 277: 1127-34.

8 Sessler DI, McGuire J, Moayeri A, Hynson J. Isofluraneinduced vasodilation minimally increases cutaneous heat loss. Anesthesiology 1991; 74: 226-32.

9 Sessler DI, McGuire J, Sessler AM. Perioperative thermal insulation. Anesthesiology 1991; 74: 875-9.

10 Just $B$, Trévien V, Delva $E$, Lienhart $A$. Prevention of intraoperative hypothermia by preoperative skin- surface warming. Anesthesiology 1993; 79: 214-8.

11 Hynson JM, Sessler DI, Moayeri A, McGuire J, Schroeder $M$. The effects of preinduction warming on temperature and blood pressure during propofol/nitrous oxide anesthesia. Anesthesiology 1993; 79: 219-28.

12 Sessler DI, Scbroeder M. Heat loss in humans covered with cotton hospital blankets. Anesth Analg 1993; 77: 73-7.

13 Hynson JM, Sessler DI. Intraoperative warming therapies: a comparison of three devices. J Clin Anesth 1992; 4: 194-9.

14 Glosten B, Hynson J, Sessler DI, McGuire J. Preanesthetic skin-surface warming reduces redistribution hypothermia caused by epidural block. Anesth Analg 1993; 77: 488-93. 
15 Vassilieff N, Rosencher N, Sessler DI, Conseiller C, Lienbart $A$. Nifedipine and intraoperative core body temperature in humans. Anesthesiology 1994; 80: 123-8.

16 Shiraki K, Sagawa S, Tajima F, Yokota A, Hasbimoto $M$, Brengelmann $G L$. Independence of brain and tympanic temperatures in an unanesthetized human. J Appl Physiol 1988; 65: 482-6. 